$33,7 \%-30$ to 40 years old, $16,3 \%-40-50$ years old, $6,5 \%$ - over 50 years old. Only 2 of $447(0,4 \%)$ victims were not citizens of Ukraine. Only $29 \%$ of victims were married (officially or de facto). However, the article emphasizes that the crimes in question are frequently committed in the context of family and domestic relations. Among the victims of unlawful deprivation of liberty or abduction $6,4 \%$ had an unfinished high school education, 49,2\% - high school education, 33,9\% - special secondary education, 10,5\% - higher education. At the moment when the crime was committed against them, $41,8 \%$ of victims were jobless or had only seasonal jobs, $39,4 \%$ were employed, $11,6 \%$ - pupils, $2,9 \%$ - retired, $4,3 \%$ entrepreneurs. Before the commitment of crimes in question, the majority of victims (near $60 \%$ ) were to a various degree acquainted with criminals (were engaged in family, marital, labor or other relations, were friends, fellow-villagers, neighbors or just knew them). The crimes in question were committed in the morning in $13,9 \%$ of cases, in the daytime in $31,8 \%$ of cases, in the evening in $37,3 \%$ of cases, and at night in $17 \%$ of cases.

People become victims of unlawful deprivation of liberty in places where they were (for example, when contrary to their will they are not allowed to leave a room or a car, are forced to stay in a house's basement, etc.). Most of the victims were captured by criminals on streets, in victims' apartments or in their vicinity.

Physical violence is frequently used towards a victim in order to unlawfully deprive a victim of liberty. As regards capturing a person and his/her abduction, physical violence happens regularly. On many occasions, physical violence is combined with psychological violence and deception.

As a rule, abducted persons are moved to short distances - mostly withing one locality (for instance, they are moved to outskirts of a town or to the nearest forest).

It is revealed in the article that in the majority of cases victims of unlawful deprivation of liberty or abduction did not resist actively.

Minimal and maximal terms victims were held by criminals vary dramatically - from 4-5 days to more than 11 months.

Unlawful withholding of victims is usually combined with causing bodily harm of different degrees, torturing, death threats, violation of human dignity.

Most typical behavior of victims of crimes in question is divided into unlawful, anti-social, neutral, incautious, and socially useful.

It concludes that a personality of a victim of unlawful deprivation of liberty and abduction plays an important (and in some particular issues - the decisive) role in the mechanism of committing this crime.

Key words: crimes against liberty, honor and dignity of the person; unlawful deprivation of liberty, abduction, victim of a crime, victimological profile, victim behavior.

DOI: $10.36695 / 2219-5521.2 .2019 .30$

удк 343.2

\title{
Н.О. АНТОНЮК
}

Наталія Олегівна Антонюк, кандидат юридичних наук, доцент, суддя Великої Палати Верховного Суду, доцент Львівського національного університету імені Івана Франка*

ORCID: 0000-0002-7582-2071

\section{КОНЦЕПЦІЇ РОЗУМІННЯ КРИМІНАЛЬНОЇ ВІДПОВІДАЛЬНОСТІ}

Постановка проблеми Поняття кримінальної відповідальності досі залишається дискусійним у наукових дослідженнях. Правильне встановлення змісту цього поняття є актуальним з огляду на використання відповідного терміна у нормативних конструкціях Кримінального кодексу України, як-от «підстава кримінальної відповідальності», «звільнення від кримінальної відповідальності» тощо. Також дефініція кримінальної відповідальності має важливе значення для встановлення змісту таких правових категорій, як «диференціація кримінальної відповідальності», «індивідуалізація кримінальної відповідальності» та ін.

Аналіз останніх досліджень і публікацій. У науці кримінального права налічується близько десяти різноманітних концепцій поняття кримінальної відповідальності. За радянського періоду цю проблему вивчали такі науковці, як: О.І. Бойцов, Я.М. Брайнін, М.І. Загородніков, М.П. Карпушин, С.Г. Келіна, B.I. Курляндський, О.Е. Лейст, А.І. Марцев, А.І. Санталов та інші. Серед українських дослідників над цією проблематикою працювали Ю.В. Баулін, В.К. Грищук, О.О. Кваша, М.І. Панов, Ю.А. Пономаренко, М.І. Хавронюк та інші вчені. Проте дискусійними залишаються не лише поняття кримінальної відповідальності, але й визначення моменту ії початку та закінчення.

Формулювання мети статті. Метою цієї статті є дослідження концепцій сутності кримінальної відповідальності, критичний аналіз змістовних ознак цієї категорії. Кінцевим результатом аналізу таких концепцій $є$ формулювання ознак, якими повинна характеризуватися кримінальна відповідальність, як кримінально-правове явище.

Виклад основного матеріалу дослідження. Розпочнемо 3 того, що чинний Кримінальний кодекс України (далі - КК України) не містить такого поняття, як «кримінальна відповідальність». Водночас цей

\section{(C) Н.O. Антонюк, 2019}

* Natalia Antoniuk, Ph.D. in Law, Associate professor, Associate professor of Ivan Franko National University of Lviv, Judge of Great Chamber of the Supreme Court 
термін активно використовується законодавцем під час конструювання різноманітних правових наслідків для особи, яка вчинила злочин. Наприклад, позитивна посткримінальна поведінка особи, яка ухилялася від сплати податків, матиме значення для звільнення ії від кримінальної відповідальності, якщо вона мала місце до притягнення такої особи до кримінальної відповідальності.

Використання термінологічного звороту «притягнення до кримінальної відповідальності» у діючому Кримінальному процесуальному кодексі України (далі - КПК), разом із його дефініцією, а також тлумачення цих питань Конституційним Судом України у рішенні від 27 жовтня 1999 р. (далі - Рішення КСУ) призводять до додаткової неоднозначності у вирішенні питання змісту та обсягу кримінальної відповідальності. Адже після прийняття Рішення КСУ законодавець у новому КПК України «змістив» часовий відлік початкового моменту притягнення до кримінальної відповідальності на етап повідомлення особі про підозру у вчиненні злочину.

У п. 22 ст. 92 Конституції України закріплено, що відповідальність за вчинення злочину визначається виключно законом, а у ч. 1 ст. 62 цього ж акта зазначено, що особа вважається невинуватою у вчиненні злочину і не може бути піддана кримінальному покаранню, доки ії вину не буде доведено в законному порядку i встановлено обвинувальним вироком суду. Інтерес становить той факт, що в Основному Законі передбачено, що особа не може бути піддана саме кримінальному покаранню, а не кримінальній відповідальності. Це ж положення продубльовано у чинному КК України. А от принцип non bis in idem у КК України сформульовано уже через заборону притягнення до кримінальної відповідальності за той самий злочин більше одного разу.

У Рішенні КСУ кримінальна відповідальність оцінюється як різновид юридичної відповідальності, особливий елемент у механізмі кримінально-правового реагування держави щодо особи, яка вчинила злочин. КСУ також розмежував поняття притягнення до кримінальної відповідальності, пов'язавши його із пред'явленням особі обвинувачення, а також момент настання кримінальної відповідальності - із набранням законної сили обвинувальним вироком суду. Проте змістовної відмінності між притягненням і настанням кримінальної відповідальності, окрім часових рамок КСУ, запропоновано не було. Разом із тим у науковій літературі неодноразово можна зустріти підхід, згідно з яким кримінальна відповідальність починається із моменту вчинення злочину, тобто саме тоді, коли виникає їі підстава. На нашу думку, це питання потребувало більш прискіпливої уваги КСУ, оскільки розділення в часі підстави відповідальності та настання відповідальності у тексті рішення обгрунтовано не було.

Отже, враховуючи недостатньо чітку законодавчу регламентацію та окремі питання щодо офіційного тлумачення, спробуємо заповнити існуючі прогалини за допомогою наукових підходів до визначення змісту, обсягу та меж кримінальної відповідальності.

Змістовно кримінальну відповідальність у науці розуміють як: 1) покарання (санкцію); 2) реальне перетерпіння негативних наслідків у зв'язку із вчиненням злочину; 3) обов'язок перетерпіти негативні наслідки у зв'язку із вчиненням злочину; 4) правовідношення; 5) частину правовідношення; 6) багатоаспектне явище, яке включає в себе як можливий негативний вплив, так і його реалізацію (законодавчий, виконавчий і судовий аспекти); 7) осуд з боку держави; 8) соціально-політичну оцінку державою вчинення злочину.

Частина науковців вважає кримінальну відповідальність ідентичною покаранню. Так, наприклад, М.М. Каплін розглядає відповідальність як абстрактний, а покарання - як конкретний термін, які, на його думку, відповідно характеризують відносно визначену санкцію та конкретну міру примусу. Судимість же цей науковець відносить до заходів кримінально-правового характеруํ․

Дещо схожий підхід обстоює M.I. Загородніков. Він пише, що кримінальна відповідальність завжди конкретна і невіддільна від іiі реального виконання, від виконання заходів примусу, передбачених у порушеній кримінально-правовій нормі ${ }^{2}$.

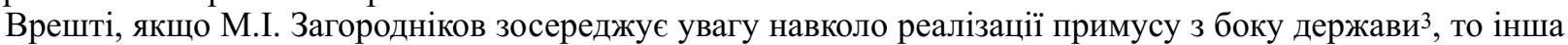
частина вчених робить акцент на реальному перетерпінні засудженим негативних наслідків вчинення ним злочину. Представниками цієї концепції є О.Е. Лейст ${ }^{4}$, а також Л.Л. Кругліков та О.В. Васільєвский, які пропонують визначати кримінальну відповідальність як перетерпіння особою, що вчинила злочин, заходів примусу у виді позбавлень і правообмежень як наслідків цього злочину з боку держави в особі його уповноважених органів у межах штрафної санкції норми кримінального закону5.

Якщо згадані вище наукові підходи в основному грунтувалися на реальному впливі на винну особу, то інша група концепцій пов'язана із потенційним впливом на винного.

Кримінальну відповідальність як обов'язок перетерпіти негативні наслідки розглядали М.I. Панов ${ }^{6}$, Ю.Б. Мельникова 7 , М.П. Карпушин та В.І. Курляндський ${ }^{8}$, Я.М. Брайнін ${ }^{9}$, П.С. Матишевський ${ }^{10}$. Вони, однак, сприймали кримінальну відповідальність як потенційний, а не реалізований обов'язок. А те, що обов'язок особи виникає у правовідношенні, стало причиною появи концепції кримінальної відповідальності як правовідносин.

Прихильники «теорії правовідношення» вважають, що у зв'язку із вчиненням злочину виникає кримінально-правове відношення ${ }^{11}$, яке характеризується взаємними правами та обов'язками особи й держави. Цей підхід має декілька варіацій. Зокрема, кримінальну відповідальність пов'язують 3 частиною такого правовідношення або, навпаки, ототожнюють з групою правовідносин, наприклад, матеріальних, процесуальних та виконавчих ${ }^{12}$.

Кримінальну відповідальність аналізують і як багатоаспектне явище. На думку Ю.В. Бауліна, кримінальну відповідальність як санкцію кримінально-правової норми можна визначити як передбачене Кримі- 
нальним кодексом обмеження прав і свобод особи, якому вона може бути піддана у майбутньому у разі вчинення злочину13. Крім того, вчений вважає, що правовою формою законодавчо визначеної кримінальної відповідальності є санкція кримінально-правової норми, передбаченої КК; індивідуально визначеної судом обвинувальний вирок суду і реально здійснюваної - діяльність органів виконавчої влади, спеціально уповноважених на виконання обвинувального вироку суду ${ }^{14}$.

Ще одну групу теорій становлять ті, у яких суть кримінальної відповідальності полягає у ролі держави у сприйнятті вчиненого злочину. Це сприйняття може об'єктивуватися у формі осуду чи у формі соціальнополітичної реакції.

Так, окремі науковці ототожнюють кримінальну відповідальність із осудом особи у зв'язку із винесенням обвинувального вироку суду ${ }^{15}$. Фактично акцент переноситься на негативну оцінку державою вчиненого винним.

Розвиваючи концепцію осуду, М.Ю. Дворецький вважає, що кримінальна відповідальність виступає і як офіційна соціально-політична реакція, і як негативна моральна оцінка державою та суспільством вчиненого злочинцем суспільно небезпечного діяння; вона водночас постає як засіб вирішення соціальних протиріч, породжених злочином, який втілює конфлікт між соціумом і його учасником ${ }^{16}$.

Отже, такий великий спектр наукових підходів, з одного боку, дещо ускладнює формування чіткого, несуперечливого уявлення про кримінальну відповідальність. 3 іншого боку, науковий плюралізм у питанні, що досліджується, дає змогу зробити певні методологічні висновки:

- по-перше, одна група вчених кримінальну відповідальність розглядає як потенційну можливість, яка може бути застосована у зв'язку із вчиненням злочину, а інша трактує її як дійсність, тобто як реальні негативні наслідки;

- по-друге, вчинення злочину призводить до появи кримінально-правового правовідношення, яке змістовно грунтується на правах і обов'язках сторін цього правовідношення. Виникнення, зміна чи припинення цього правовідношення пов'язані з підставою кримінальної відповідальності;

- по-третє, кримінальна відповідальність є видом юридичної відповідальності, яка у свою чергу є видом соціальної відповідальності, і механічне перенесення положень теоретичних досліджень цих явищ на кримінальну відповідальність не сприяє врахуванню змісту ії спеціальних ознак, які, власне, конкретизують видове поняття порівняно з родовим.

У найбільш спрощеному варіанті соціальну відповідальність розуміють як елемент взаємодії між індивідом і колективом, індивідом і суспільством тощо ${ }^{17}$. Очевидно, що як і будь-яка відповідальність, соціальна відповідальність повинна грунтуватися на правилах поведінки, соціальних нормах, бо не можна уявити відповідальність, яка б існувала поза межами будь-якого регулювання.

На думку П.М. Рабіновича, соціальна норма - це «зумовлене об'єктивними закономірностями правило фізичної поведінки (діяльності), яке має загальний характер, виражає волю певної частини або всього суспільства і забезпечується різними засобами соціального впливу» ${ }^{18}$. Звідси, власне, і виводиться зміст соціальної відповідальності як механізму забезпечення діяльності особи, яка не вступала б у протиріччя 3 волею частини або всього суспільства. Соціальна відповідальність повинна виходити із соціальної норми, яка передбачає можливість забезпечення їі виконання засобами соціального впливу.

У літературі також зазначають, що соціальна відповідальність - це діалектичний взаємозв'язок між особою і суспільством, який знаходить своє відображення в добровільній реалізації соціальних норм, що тягне за собою схвалення і заохочення, а у випадках поведінки, яка не відповідає приписам цих норм, - обов'язок перетерпіти негативні наслідки і їх перетерпіння ${ }^{19}$.

Т.О. Чепульченко пропонує визначити соціальну відповідальність як систему відносин між людьми в межах необхідної їм поведінки, вимог суспільства до індивіда, і як невідворотність відзвітувати за свою поведінку 20 .

Таким чином, ми можемо спостерігати плюралізм міркувань щодо розуміння як соціальної, так і кримінальної відповідальності. До змісту останнього з цих понять різні науковці включають як відносини, так і обов'язки зазнати негативних наслідків, а також і самі ці наслідки. Очевидно, що за такого різноманіття поглядів щодо загального поняття, похідні від нього родові та видові поняття будуть грунтуватися на одному iз підходів, який конкретний вчений вважає більш логічним та правильним. А, отже, зміст явища кримінальної відповідальності необхідно встановлювати не на основі механічного відтворення змісту загального поняття соціальної відповідальності, а виходячи із суті явища відповідальності та його ознак.

Л.Л. Кругліков та О.В. Васільєвський співвідносять соціальну та кримінальну відповідальність як загальне і одиничне, а юридичну відповідальність - як спеціальне. На думку цих науковців, для соціальної відповідальності характерним є осуд порушника і його вчинку, проте для кримінальної відповідальності такого тлумачення не достатньо, оскільки осудом кримінальна відповідальність не обмежується ${ }^{21}$. У зв'язку 3 цим виникає питання, як з точки зору формальної логіки одиничне може містити ознаки, що виходять за межі загального. Очевидно, що з точки зору логіки співвідношення понять, загальне є абстрактним, в той час як спеціальне і окреме, відповідно, містять різні рівні конкретизації загального. Тому соціальна, юридична та кримінальна відповідальність повинні характеризуватися однаковим набором ознак, з різним рівнем узагальнення і конкретизації.

Юридичну відповідальність теж по-різному розуміють у теорії права. С.С. Алєксєєв визначає ії як застосування до правопорушника передбачених санкцією юридичної норми заходів державного примусу, що 
виражаються у формі позбавлень особистого, організаційного чи майнового характеру 22. Натомість, П.М. Рабінович трактує юридичну відповідальність як «закріплений у законодавстві і забезпечуваний державою юридичний обов'язок правопорушника зазнати примусового позбавлення певних благ, що йому належали» ${ }^{23}$. І.О. Кузьмін розділяє юридичну відповідальність на об'єктивний та суб'єктивний аспекти. Об'єктивний - це закріплені в санкціях правових норм засоби державного примусу у виді позбавлень особистого, майнового чи організаційного характеру, які можуть бути застосовані до особи за вчинення протиправного діяння, а суб'єктивний аспект - це суб'єктивний обов'язок особи перетерпіти заходи державного примусу у виді позбавлень особистого, майнового чи організаційного характеру за вчинене протиправне діяння 24.

С.С. Алєксєєв, аргументуючи визначення юридичної відповідальності крізь призму «застосування засобів примусу», писав, що це тлумачення витікає зі змісту чинного законодавства. Так, вчинення особою діянь, заборонених кримінальним законом, ще не тягне за собою юридичної відповідальності. Більше того, до відповідного рішення (вироку) суду особа взагалі вважається невинуватою, а, отже, і не підлягає кримінальній відповідальності 25 .

Навряд чи можна беззастережно погодитися з цією тезою. В обвинувальному вироку суду констатується вина особи у вчиненні злочину. Неможливість осуду особи до набрання вироком законної сили $є$ елементом гарантії прав та свобод особи від свавільного негативного впливу з боку державних органів чи інших осіб. Фактично особа є злочинцем уже на час вчинення посягання, яке містить усі необхідні ознаки складу злочину, а у рішенні суду цей факт отримує своє підтвердження і правове закріплення.

Суд також не може звільнити від відповідальності вже засуджену особу, хоча може звільнити ії від покарання чи його відбування, що також вказує на відмінність між відповідальністю і заходом примусу.

Врешті, не даремно строки давності у разі звільнення від кримінальної відповідальності обчислюються від моменту вчинення злочину, а не від процесуальної констатації вини у судовому рішенні.

Висновки. Викладене вище допомагає підсумувати, що будь-який вид відповідальності містить певну низку типових ознак. По-перше, відповідальність виникає у зв'язку із існуванням тих чи інших суспільних відносин. Поза суспільними відносинами відсутні правила поведінки та оцінка соціумом їх виконання чи невиконання. По-друге, відповідальність закріплюється у правилах поведінки. Для різних видів відповідальності ці правила поведінки можуть набувати різних форм та змістовних наповнень, що, однак, не змінює основного їх призначення, а саме регулювання суспільних відносин в інтересах домінуючої частини соціуму. По-третє, відповідальність набуває обов'язкового характеру для особи у разі порушення правила. По-четверте, реальне застосування заходів відповідальності не може змінювати їі змісту та обсягу щодо підстави (порушення реальним діянням правила поведінки), що передбачає необхідність розмежовувати відповідальність та її реалізацію. По-п'яте, відповідальність змістовно передбачає потенційні негативні наслідки для особи. По-шосте, відповідальність носить елемент примусу.

1 Каплин М.Н. Уголовная ответственность и наказание: соотношение базовых категорий уголовного права. Вестник института Вологда. 2009. № 08. С. 11. C. 42 .

2 Загородников Н.И. О пределах уголовной ответственности. Советское государство и право. Москва, 1967. № 7 (июль).

3 Там само. С. 39.

4 Лейст О.Э. Санкции и ответственность по советскому праву (теоретические проблемы). Москва: Изд-во МГУ, 1981. С. 238.

5 Кругликов Л.Л., Васильевский А.В. Дифференциация ответственности в уголовном праве. Санкт-Петербург: Изд-во «Юридический центр Пресс», 2002. С. 34.

6 Панов Н. Уголовная ответственность: понятие, принципы, основание. Ежегодник украинского права 2013. № 5. С. 546.

${ }^{7}$ Мельникова Ю.Б. Дифференциация ответственности и индивидуализация наказания. Красноярск: Изд-во Краснояр. унта, 1989. С. 9.

8 Карпушин М.П., Курляндский В.И. Уголовная ответственность и состав преступления. Москва: Юрид. лит., 1974. С. 21.

9 Брайнин Я.М. Уголовная ответственность и ее основания в советском уголовном праве. Москва, 1963. С. 25.

10 Матишевський П.С. Кримінальне право України. Загальна частина: підручник. Київ: К.: А. С. К. 2001. С. 86.

11 Лесниевски-Костарева Т.А. Дифференциация уголовной ответственности. Теория и законодательная практика. Москва: Норма, 1998. 296 с.; Наумов А.В. Российское уголовное право. Общая часть: Курс лекций. Москва: БЕК, 1996. С. 258.

12 Марцев А.И. Уголовная ответственность и общее предупреждение преступлений: учеб. пособ. Омск: НИиРИО Ом. ВШМ МВД СССР, 1973. С. 23.

13 Баулін Ю.В. Звільнення від кримінальної відповідальності: монографія. Київ: Атіка, 2004. С. 27.

14 Там само. С. 30.

15 Бойцов А.И. Понятие уголовной ответственности. Вестник ЛГУ. 1981. № 17. С. 122; Санталов А.И. Теоретические вопросы уголовной ответственности. Ленинград: Изд-во Ленингр. ун-та, 1982. С. 30; Хомич В.М. Теоретические проблемы уголовной ответственности (Концепция и правовая модель института уголовной ответственности) : автореф. дисс. ... д-ра юрид. наук. Минск, 1997. С. 18-34.

16 Дворецкий М.Ю. Уголовная ответственность в отечественном законодательстве в контексте эффективности реализачии: проблемы теории и практики применения. Вестник ТГУ. 2014. Вып. 2 (130). С. 208.

17 Ивахненко С.Н. Юридическая и социальная ответственность: проблемы понимания и соотношения. Юридические исследования. № 1 Ставрополь: ФГАОУ ВПО «Северо-Кавказский федеральный університет», 2013. С. 25.

18 Рабінович П.М. Основи загальної теорії права та держави: навч. посіб. 9-е вид. зі змінами. Львів: Край, 2007. С. 88.

19 Калениченко Л. Социальная ответственность: понятие и признаки. Legea si viata= Закон и Жизнь: междунар. науч.практ. журн. 2015. № 4/4 (Aprilie). С. 33. 
20 Чепульченко Т.О. Соціальна відповідальність: поняття та сутність. Вісник НТУУ «КПІ». Політологія. Соціологія. Право : зб. наук. праць. 2010. № 1 (5). С. 137-142. С. 141.

21 Кругликов Л.Л., Васильевский А.В. Вказана праця. С. 18.

22 Алексеев С.С. Теория государства и права: учебник для ВУЗОВ. 3-е изд., Изд-во НОРМА. 2005. С. 184.

23 Рабінович П.М. Вказана праця. С. 161.

24 Кузьмин И.А. Юридическая ответственность и ее реализация: учеб. пособ.. Иркутск: Изд-во ИГУ, 2013. С. 24.

25 Алексеев С.С. Вказана праця. С. 250.

\section{References:}

Alekseev, S.S. (2005). Teorija gosudarstva i prava Uchebnik dlja vuzov. NORMA, 458 [in Russian].

Baulin, Yu.V. (2004). Zvilnennia vid kryminalnoi vidpovidalnosti K.: Atika, 296 [in Ukrainian].

Bojcov, A.I. (1981). Ponjatie ugolovnoj otvetstvennosti. Vestnik LGU. 17, 121-124 [in Russian].

Brajnin, Ja.M. (1963). Ugolovnaja otvetstvennost' i ee osnovanija v sovetskom ugolovnom prave. M., 275 [in Russian].

Dvoreckij, M.Ju. (2014). Ugolovnaja otvetstvennost' v otechestvennom zakonodatel'stve v kontekste effektivnosti realizacii: problemy teorii i praktiki primenenija. Vestnik TGU. 2, 205-212 [in Russian].

Zagorodnikov, N.I. (1967). O predelah ugolovnoj otvetstvennosti. Sovetskoe gosudarstvo i pravo. 7, 39-46 [in Russian].

Ivahnenko, S.N. (2013). Juridicheskaja i social'naja otvetstvennost': problemy ponimanija i sootnoshenija Stavropol': FGAOU $V P O ~ «$ Severo-Kavkazskij federal'nyj universitet». 1, 25-29 [in Russian].

Kalenichenko, L. (2015). Social'naja otvetstvennost': ponjatie i priznaki. Legea si viata= Zakon i Zhizn': mezhdunar. nauch.prakt. zhurn 4, 30-34 [in Russian].

Kaplin, M.N. (2009). Ugolovnaja otvetstvennost' i nakazanie: sootnoshenie bazovyh kategorij ugolovnogo prava. Vestnik instituta. 8, 9-12 [in Russian].

Karpushin, M.P., Kurl'andskij, V.I. (1974). Ugolovnaja otvetstvennost' i sostav. M.: Jurid. Lit., 232 [in Russian]

Kruglikov, L.L., Vasil'evskij, A.V. (2002). Differenciacija otvetstvennosti v ugolovnom prave Spb.: «Juridicheskij centr Press», 300 [in Russian].

Kuz'min, I.A. (2013). Juridicheskaja otvetstvennost' i ee realizacija: uchebnoe posobie. Irkutsk:IGU, 219 [in Russian].

Lejst, O.Je. (1981). Sankcii i otvetstvennost' po sovetskomu pravu (teoreticheskie problemy). M.: MGU, 240 [in Russian].

Lesnievski-Kostareva, T.A. (1998). Differenciacija ugolovnoj otvetstvennosti. Teorija i zakonodatel'naja praktika. M.: Norma. 296 [in Russian].

Marcev, A.I. (1973). Ugolovnaja otvetstvennost' i obshhee preduprezhdenie prestuplenij. Uchebnoe posobie. Omsk: NIiRIO Om. VShM MVD SSSR, 96 [in Russian].

Matyshevskyi, P.S. (2001). Kryminalne pravo Ukrainy. Zahalna chastyna. Kyiv: A. S. K., 352 [in Ukrainian].

Mel'nikova, Ju.B. (1989). Differenciacija otvetstvennosti i individualizacija nakazanija. Krasnojarsk: Izd-vo Krasnojar. Unta, 120 [in Russian].

Naumov, A.V. (1996). Rossijskoe ugolovnoe pravo. Obshhaja chast': Kurs lekcij. M.: BEK, 560 [in Russian].

Panov, N. (2013). Ugolovnaja otvetstvennost': ponjatie, principy, osnovanie. Ezhegodnik ukrainskogo prava. 5, 543 [in Russian]. Rabinovych, P. M. (2007). Osnovy zahalnoi teorii prava ta derzhavy. Navch. Posibnyk. Lviv: Krai, 192 [in Ukrainian].

Santalov, A I. (1982). Teoreticheskie voprosy ugolovnoj otvetstvennosti. L: Izd-vo Leningr. un-ta, 96 [in Russian].

Homich, V.M. (1997). Teoreticheskie problemy ugolovnoj otvetstvennosti (Koncepcija i pravovaja model' instituta ugolovnoj otvetstvennosti). Avtoref. diss. ... d.ju.n. Minsk, 18-34 [in Russian].

Chepulchenko, T.O. (2010). Sotsialna vidpovidalnist: poniatia ta sutnist Visnyk NTUU «KPI». Politolohiia. Sotsiolohiia. Pravo : zbirnyk naukovykh prats. 1, 137-142 [in Ukrainian].

\section{Резюме}

Антонюк Н.О. Концепції розуміння кримінальної відповідальності.

У статті розглядаються концепції кримінальної відповідальності, наводяться їх ключові положення та висловлюються критичні зауваження щодо них. Здійснено спробу системно оцінити кримінальну відповідальність у розрізі теоретичних конструкцій соціальної та юридичної відповідальності. Висловлено заперечення щодо механічного перенесення ознак цих явищ на кримінальну відповідальність без чіткого розуміння, на якій концепції базується відповідне поняття. Зроблено висновок, що соціальна, юридична та кримінальна відповідальності повинні характеризуватися однаковим набором ознак 3 різним рівнем узагальнення та конкретизації.

Констатовано недоліки основних теорій кримінальної відповідальності, а також запропоновано ознаки, які характеризують кримінальну відповідальність.

Ключові слова: кримінальна відповідальність, злочин, санкція, правовідношення, юридична відповідальність, осуд.

Резюме

\section{Антонюк Н.О. Концепции понимания уголовной ответственности.}

В статье рассматриваются концепции уголовной ответственности, приводятся их ключевые положения и высказываются критические замечания. Совершена попытка системно оценить уголовную ответственность в разрезе теоретических конструкций социальной и юридической ответственности. Выражено возражение касательно механического переложения признаков этих категорий на уголовную ответственность без четкого понимания, на какой концепции базируется соответствующее понятие. Сделано вывод о том, что социальная, юридическая и уголовная ответственности должны характеризироваться одинаковым набором признаков с разным уровнем обобщения и конкретизации.

Констатированы недочеты основных теорий уголовной ответственности, а также предложены признаки, которые характеризируют уголовную ответственность.

Ключевые слова: уголовная ответственность, преступление, санкция, правоотношение, юридическая ответственность, осуждение. 


\section{Summary}

Natalia Antoniuk. Concepts of understanding of criminal responsibility.

Definition of criminal responsibility is still discussed in scientific researches. Adequate understanding of this term is actual concerning its use in legal constructions of Criminal Code of Ukraine. For example, "basis of criminal responsibility", "exemption from criminal responsibility" etc. It is worth mentioning that definition of criminal responsibility is of great importance while determining the essence of such legal categories as differentiation of criminal responsibility, individualization of criminal responsibility and others.

This research is aimed towards determination of features of criminal responsibility. Understanding of such institution of criminal law as differentiation of criminal responsibility and others categories of criminal law depend on this to a considerable extent.

Concepts of criminal responsibility are examined in the article. Their main features are stated and criticized. Official interpretation made by Constitutional Court of Ukraine concerning moment of beginning of criminal responsibility and engagement to criminal responsibility are analyzed.

Attempt is made to evaluate systematically criminal responsibility in terms of theoretical constructions of social and legal responsibilities. We object the possibility of mechanical understanding of these categories similarly to criminal responsibility without clear vision on which concept each of the definitions are based. Conclusion is made that social, legal and criminal responsibilities shall be described with the same features but with the different level of generalization and concretization

On the basis of this research shortcomings of main theories of criminal responsibility are stated. Features describing criminal responsibility as criminal-legal category are suggested.

Key words: criminal responsibility, crime, sanction, legal relationship, legal responsibility, condemnation.

DOI: 10.36695/2219-5521.2.2019.31

УДК 343.137(477)(073)

\section{І.В. МУДРАК}

Інна Василівна Мудрак, кандидат юридичних наук, доцент Національного університету «Одеська юридична академія»*

ORCID: 0000-0003-2456-0515

\section{ЩОДО ВИЗНАННЯ ОСОБИ ПОТЕРПІЛОЮ У КРИМІНАЛЬНОМУ ПРОВАДЖЕННІ}

Постановка проблеми. Аналізуючи главу 3 КПК України «Суд, сторони та інші учасники кримінального провадження», стає зрозуміло, що законодавець виділив потерпілого та його представника в окрему особливу категорію, вивівши із кола сторін кримінального провадження (§4 «Потерпілий і його представник»). Правове регламентування процесуального становища потерпілого та його представника в окремому параграфі (§4) пояснюється, на думку В.В. Вапнярчука, по-перше, необхідністю підкреслити значущість у кримінальному провадженні особи, постраждалої від учинення щодо неї кримінального правопорушення, й важливість захисту ії прав і законних інтересів; по-друге, необов'язковістю в кожному кримінальному провадженні здійснення потерпілим функції обвинувачення й таким чином не завжди його перебуванням на стороні обвинувачення (п. 19 ст. 3 КПК). Цей суб’єкт у конкретних кримінальних провадженнях може інколи виконувати зовсім іншу кримінальну процесуальну функцію, зокрема, сприяння правосуддю, а інколи й захисту ${ }^{1}$. Хоча, слід зауважити, участь потерпілого у кримінальному провадженні здебільшого має обвинувальний характер, оскільки він заінтересований викрити особу у вчиненому кримінальному правопорушенні, адже лише в такому випадку він з великою ймовірністю зможе одержати відшкодування заподіяної кримінальним правопорушенням шкоди.

Досліджуючи проблеми визнання особи потерпілою, хотілося б погодитись, що проблема тут полягає насамперед ось у чому - якщо слідчий/прокурор з боку обвинувачення та підозрюваний, обвинувачений разом з адвокатами, з боку захисту, мають відносно рівні повноваження, то потерпілий позбавлений багатьох процесуальних можливостей, що, очевидно, не відповідає щонайменше двом засадам кримінального провадження: рівності перед законом і судом та змагальності сторін, свободи в поданні ними суду своїх доказів та у доведенні перед судом їх переконливості (ст. ст. 7, 10, 22 КПК України)2.

Аналіз останніх досліджень і публікацій. Важливі питання досліджуваної проблеми розглядали багато вітчизняних учених, зокрема, І.В. Гловюк, Л.М. Гуртієва, О.П. Кучинська, Т.В. Лукашкіна, М.А. Островська, В.Г. Пожар, В.П. Шибіко. Водночас, не применшуючи значення цих та багатьох інших досліджень, зазначимо, що спірним у кримінально-процесуальній науці залишається визначення моменту визнання особи потерпілою в кримінальному провадженні, а процесуальна канва комунікативних проблем визнання особи потерпілою включає цілу низку досі невирішених в КПК України процедурних неузгодженостей.

Формулювання мети статті. Виходячи 3 цих міркувань, мета даної статті полягає у напрацюванні окремих змін до чинної редакції КПК України в частині визнання особи потерпілою у кримінальному про-

(C) І.В. Мудрак, 2019

* Inna Mudrak, Ph.D. in Law, Associate professor of the National University "Odessa Academy of Law" 